\title{
PROBLEMATYKA BEZPIECZEŃSTWA ENERGETYCZNEGO W KAMPANII WYBORCZEJ BRONISŁAWA KOMOROWSKIEGO I ANDRZEJA DUDY NA URZĄD PREZYDENTA POLSKI W 2015 ROKU
}

\author{
Michał Paszkowski \\ Instytut Europy Środkowej w Lublinie \\ ORCID ID: https://orcid.org/0000-0002-2751-8550 \\ e-mail: michal.paszkowski@ies.lublin.pl
}

\begin{abstract}
Streszczenie: W artykule zostały przeanalizowane koncepcje formułowane przez dwóch głównych kandydatów na urząd prezydenta Polski w 2015 roku. Celem artykułu była zatem analiza pomysłów Bronisława Komorowskiego i Andrzeja Dudy w zakresie zapewnienia bezpieczeństwa energetycznego państwa oraz określenie potencjalnych punktów zbieżnych formułowanych koncepcji politycznych. Poglądy obu kandydatów różniły się znacząco, co wynikało z odmiennej wizji prezentowanej przez dwa główne ugrupowania polityczne w Polsce - Platformę Obywatelską oraz Prawo i Sprawiedliwość, które popierały tych kandydatów.
\end{abstract}

Słowa kluczowe: Bronisław Komorowski; Andrzej Duda; bezpieczeństwo energetyczne; myśl polityczna

\section{UWAGI WSTĘPNE}

Niestabilna sytuacja polityczna w Europie Środkowo-Wschodniej (wojna rosyjsko-ukraińska, aneksja Półwyspu Krymskiego przez Rosję) w sposób szczególny rzutowała na zakres tematyczny prezydenckiej kampanii wyborczej z 2015 roku. W ramach przeprowadzonej debaty publicznej jednym z ważniejszych zagadnień poruszanych w enuncjacjach politycznych kandydatów na urząd prezydenta Rzeczypospolitej Polskiej była sprawa bezpieczeństwa energetycznego państwa. W sposób szczególny kwestia ta była poruszana przez Bronisława Komorowskiego, prezydenta RP w latach 2005-2010 popieranego 
przez Platformę Obywatelską oraz Andrzeja Dudę, polityka ugrupowania Prawo i Sprawiedliwość ${ }^{1}$.

Sytuacja energetyczna Polski, w tym uzależnienie od dostaw surowców energetycznych z Rosji, była w zróżnicowany sposób oceniana przez polskie ugrupowania polityczne, a w efekcie również przez kandydatów desygnowanych przez poszczególne partie do wyborów prezydenckich. Niewątpliwie każdy ze startujących osób miał własną wizję zapewnienia bezpieczeństwa energetycznego Polski, która była uwarunkowana m.in. poglądami na rolę państwa w gospodarce, a także preferowanym zakresem współpracy gospodarczej z eksporterami surowców energetycznych.

Celem artykułu była analiza pomysłów Bronisława Komorowskiego i Andrzeja Dudy - kandydatów na urząd prezydenta Polski z okresu kampanii wyborczej w 2015 roku - w zakresie zapewnienia bezpieczeństwa energetycznego państwa oraz określenie potencjalnych punktów zbieżnych formułowanych koncepcji politycznych. W pracy wykorzystano jedynie materiały, źródła i wypowiedzi tych dwóch polityków, które były wykorzystywane w okresie kampanii wyborczej, a nie w innym okresie aktywności politycznej ${ }^{2}$. Zasadniczym założeniem było twierdzenie, iż stanowisko obu kandydatów na kwestie energetyczne było zróżnicowane, z uwagi na odmienną wizję Polski prezentowaną przez dwa główne ugrupowania polityczne w Polsce - Platformę Obywatelską oraz Prawo i Sprawiedliwość. W efekcie analiza śladów i świadectw myśli politycznej, pozwala w dogłębny sposób przeanalizować poglądy podmiotów politycznych (w tym przypadku także partii politycznych), których kandydaci byli reprezentantami. Podjęcie badanego tematu było istotne, z uwagi na brak opracowań, w których można znaleźć efekty autorskich studiów dotyczących stanowiska Bronisława Komorowskiego oraz Andrzeja Dudy w kontekście zapewnienia bezpieczeństwa energetycznego Polski.

\section{OBRONA BRONISŁAWA KOMOROWSKIEGO DOKONAŃ RZĄDOWYCH W ZAKRESIE ENERGETYKI}

Niewątpliwie duży wpływ na formułowane w trakcie kampanii prezydenckiej przez Bronisława Komorowskiego pomysły w zakresie zapewnienia bezpieczeństwa energetycznego państwa miała sprawowana przez Platformę Obywatelską

\footnotetext{
1 Analiza koncepcji różnych aktorów politycznych (ugrupowania, politycy) w odniesieniu do zapewnienia bezpieczeństwa energetycznego państwa stanowi zagadnienie będące przedmiotem badań nad myślą polityczną partii politycznych [Paszkowski 2015].

2 W artykule nie została przeanalizowana aktywność Bronisława Komorowskiego oraz Andrzeja Dudy, z okresu sprawowania przez nich funkcji prezydenta RP, a także Sekretarzy Stanu w Kancelarii Prezydenta RP, doradców prezydentów RP lub też Biura Bezpieczeństwa Narodowego, chociaż autor ma pełną świadomość podejmowania wielokrotnie przez tych dwóch polityków w trakcie działalności politycznej, w tym różnego rodzaju debat i dyskusji, zagadnień z zakresu bezpieczeństwa energetycznego Polski.
} 
wspólnie z Polskim Stronnictwem Ludowym w latach 2007-2015 władza polityczna. Prezydent wywodzący się ze środowiska liberalnego prezentując pomysły w zakresie spraw energetycznych odnosił się wielokrotnie do działań podejmowanych przez rząd zarówno premiera Donalda Tuska, jak i premier Ewy Kopacz. W efekcie, mając na względzie znaczenie tematyki bezpieczeństwa energetycznego w debacie politycznej w Polsce, nakreślał wizję polityki energetycznej zbieżną ze swoim zapleczem politycznym, czyli Platformą Obywatelską.

W ramach prowadzonej kampanii wyborczej prezydent Bronisław Komorowski formułował ograniczoną liczbę pomysłów w zakresie zapewnienia bezpieczeństwa energetycznego Polski (w tym okresie kluczowym punktem kampanii były inne zagadnienia). Niemniej centralnym punktem prezentowanego stanowiska wobec kwestii energetycznych było zagadnienie restrukturyzacji sektora węglowego. Jedocześnie w enuncjacjach politycznych prezydent podnosił kilka istotnych zagadnień, przy czym pewna wizja polityki energetycznej została zaprezentowana $\mathrm{w}$ dokumentach programowych.

Poglądy urzędującego wówczas prezydenta Polski na zagadnienia energetyczne były odzwierciedleniem stanowiska rządu Platformy Obywatelskiej i Polskiego Stronnictwa Ludowego na rozwój poszczególnych gałęzi gospodarki. W efekcie dla B. Komorowskiego ważnym elementem polityki energetycznej była restrukturyzacja górnictwa węgla kamiennego. Z uwagi na niekorzystną sytuację na rynku węgla (spadek zapotrzebowanie na surowiec wywołany polityką klimatyczną różnych państw), która skutkowała niską ceną tego surowca na rynkach międzynarodowych, kopalnie w Polsce w latach 2014-2015 znajdowały się w trudnej sytuacji finansowej. Dla rządu PO-PSL niezbędne było zaproponowanie rozwiązań służących poprawie kondycji finansowej znajdujących się w trudnej sytuacji biznesowej spółek węglowych. Wprowadzony w 2015 roku inicjatywą poselską projekt restrukturyzacji Kompanii Węglowej S.A. spotkał się z aprobatą prezydenta B. Komorowskiego. W ocenie kandydata Platformy Obywatelskiej były to niezbędne działania umożliwiające wprowadzenie ram prawnych służących restrukturyzacji kopalń węgla kamiennego (Ustawa służy...). Formułowane stanowisko było związane ze znaczeniem tego surowca w wytwarzaniu energii elektrycznej i dlatego też prezydent wyrażał przekonanie, że „węgiel jest i będzie długo jeszcze jednym z najważniejszych, strategicznych surowców energetycznych" (Bronisław Komorowski złożył życzenia...).

W ramach prezentowanych opinii na tematy energetyczne prezydent opowiadał się za dywersyfikacją źródeł i kierunków dostaw ropy naftowej i gazu ziemnego do Polski. W tym zakresie pozytywnie oceniał działania podejmowane przez spółki sektora naftowego i gazowego w okresie rządów PO-PSL. W sposób szczególny - co było charakterystyczne dla liberalnej myśli politycznej - podnosił aspekt rozbudowy infrastruktury energetycznej służącej zróżnicowaniu dostaw surowców energetycznych. W tym kontekście podnosił znaczenie terminalu naftowego w Gdańsku dla zapewnienia zróżnicowanej struktury dostaw ropy naftowej do polskich rafinerii, natomiast $\mathrm{w}$ odniesieniu do gazu ziemnego rozbudowane 
połączenia międzysystemowe z Czechami i Niemcami (tzw. interkonektory). Niemniej w ograniczonym zakresie wskazywał na źródło pochodzenia surowca.

Jednym z kluczowych aspektów kampanii wyborczej na urząd prezydenta RP w 2015 roku była kwestia budowy terminalu regazyfikacyjnego w Świnoujściu. Z uwagi na opóźnienia $\mathrm{w}$ realizacji inwestycji prezydent B. Komorowski nie wypowiadał się zasadniczo na ten temat, pozostawiając tę kwestię rządowi, który informował opinię publiczną o postępach w realizacji inwestycji. Niemniej zaplecze prezydenta dostrzegało znaczenie terminala LNG dla bezpieczeństwa energetycznego Polski. W tym kontekście podkreślano, że powstająca infrastruktura (terminal w Świnoujściu miał mieć docelowo zdolności rozładunkowe na poziomie 7,5 mld $\mathrm{m}^{3}$ gazu ziemnego rocznie) wspólnie z planowanymi połączeniami międzysystemowymi ze Słowacją, Litwą oraz rozbudową połączenia z Republiką Czeską miało doprowadzić do zapewnienia dostaw gazu ziemnego z różnych kierunków i źródeł oraz zintegrowania polskiego rynku gazu ziemnego z europejskim (Plan Działań dla Polski...). Prowadzone inwestycje były elementem szerszego projektu firmowanego przez rządy D. Tuska oraz E. Kopacz obejmującego powstanie europejskiego korytarza gazowego Północ-Południe, który miał połączyć terminal LNG w Świnoujściu (Polska) z terminalem LNG na wyspie Krk (Chorwacja). W ramach tej inicjatywy istniałaby możliwość swobodnej wymiany gazu ziemnego wśród państw Europy Środkowej, co miało kluczowe znaczenie w sytuacji przerw w dostawach surowca z kierunku dominującego dla większości państw tego regionu, czyli Rosji.

Innym projektem wspieranym przez kandydata Platformy Obywatelskiej była idea Unii Energetycznej (Paszkowski 2017). Zaproponowany przez premiera Donalda Tuska w 2014 roku projekt miał docelowo doprowadzić do zwiększenia bezpieczeństwa energetycznego państw Unii Europejskiej oraz przyczynić się do większej koordynacji polityki energetycznej w Europie. W ocenia B. Komorowskiego była to słuszna inicjatywa umożliwiająca ,przełamywanie partykularnych interesów” oraz budowanie „solidarności energetycznej” pomiędzy państwami członkowskimi. W efekcie przewidywano, że projekt powinien „zwiększyć skuteczność mechanizmów reagowania kryzysowego oraz umożliwić wykorzystywanie różnorodności konwencjonalnych i niekonwencjonalnych potencjałów energetycznych państw członkowskich" (Plan Działań dla Polski...). Niewątpliwie sformułowany projekt był uwarunkowany zmienioną sytuacją międzynarodową, a w swoim założeniu, był nakierowany na aktywne przeciwdziałanie zagrożeń dla bezpieczeństwa Europy. Uwzględniając uzależnienie Polski od dostaw surowców energetycznych z Rosji prezydent negatywnie oceniając istniejącą zależność popierał starania na rzecz zwiększenia bezpieczeństwa Polski.

Podsumowując, należy stwierdzić, że duży wpływ na proponowaną przez Bronisława Komorowskiego, kandydata Platformy Obywatelskiej na urząd prezydenta RP, wizję polityki energetycznej miały projekty energetyczne, w tym infrastrukturalne realizowane $\mathrm{w}$ trakcie sprawowania przez koalicję PO-PSL władzy w Polsce. Niemniej - dla przykładu - stanowisko B. Komorowskiego 
w zakresie funkcjonowania sektora węglowego było uwarunkowane znaczeniem tego surowca w gospodarce Polski i dlatego też pominięcie tego zagadnienia w kampanii wyborczej było niemożliwe. W odniesieniu do pozostałych kwestii energetycznych poruszanych w enuncjacjach politycznych przez kandydata PO (rozbudowa infrastruktury energetycznej, idea Unii Energetycznej) należy podkreślić, iż nie stanowiły pierwszorzędnego przekazu politycznego, gdyż tematyka energetyczna nie stanowiła trzonu kampanii wyborczej Bronisława Komorowskiego na urząd prezydenta RP w 2015 roku.

\section{POMYSŁY ANDRZEJA DUDY Z OKRESU KAMPANII WYBORCZEJ}

Formułowane przez Andrzeja Dudę, kandydata partii Prawo i Sprawiedliwość na urząd prezydenta Polski, koncepcje w zakresie zwiększenia poziomu bezpieczeństwa energetycznego oraz ogólnie dotyczące gospodarki były związane ze stanowiskiem jego ugrupowania na tego typu kwestie. Z uwagi na pełnioną przez PiS w 2015 roku rolę partii opozycyjnej, kandydat tego ugrupowania w dużej mierze krytycznie odnosił się do wielu projektów realizowanych przez rząd koalicji PO-PSL w aspekcie energetycznym. Niemniej prezentując własne stanowisko na zagadnienia związane z energetyką, nakreślał autorską wizję polityki energetycznej państwa.

Spośród kluczowych dla rozwoju państwa dziedzin gospodarki Andrzej Duda szczególną uwagę w kampanii wyborczej przywiązał do dwóch zagadnień mających jednocześnie istotne znaczenie dla bezpieczeństwa energetycznego Polski. W centrum uwagi kandydata Prawa i Sprawiedliwości pozostawały kwestie: 1) dywersyfikacji dostaw gazu ziemnego poprzez budowę terminalu regazyfikacyjnego (LNG) na terytorium Polski; 2) wykorzystania węgla kamiennego w krajowej gospodarce.

Andrzej Duda w ramach prowadzonej kampanii wyborczej w enuncjacjach politycznych akcentował potrzebę zakończenia w Polsce - zainicjonowanej przez Prawo i Sprawiedliwość w 2007 roku - budowy terminalu regazyfikacyjnego w porcie Szczecin-Świnoujście. Formułowany pogląd wynikał z ogólnej potrzeby obejmującej zapewnienia bezpieczeństwa energetycznego Polski, z uwagi na duże uzależnienie od dostaw gazu ziemnego z Rosji. Jednocześnie kandydat PiS na prezydenta RP podkreślał, że realizacja inwestycji była szczególnie istotna z uwagi na sytuację polityczną w Europie Środkowo-Wschodniej, w tym przede wszystkim aneksję Półwyspu Krymskiego przez Rosję oraz wojnę na Ukrainie (Andrzej Duda: Jak patrzy się...). A. Duda dowodził, że terminal LNG dawała Polsce kilka zasadniczych korzyści. Po pierwsze - stwarzał zabezpieczenie przed możliwością zastosowania przez Rosję szantażu energetycznego. W ocenie kandydata PiS na urząd prezydenta niekorzystny bilans energetyczny Polski w kontaktach handlowych z Rosją w zakresie dostaw surowców energetycznych wymuszał realizację inwestycji umożliwiających fizyczną dywersyfikację. W efekcie jedynie rozbudowa infrastruktury energetycznej m.in. poprzez budowę instalacji 
energetycznych umożliwiała realizację tego postulatu. Po drugie - dawał możliwość zwiększenia bezpieczeństwa energetycznego poprzez zróżnicowanie źródeł i kierunków dostaw gazu ziemnego (Andrzej Duda: Jak patrzy się...). Powstanie terminalu regazyfikacyjnego stwarzało sposobność do zwiększenia swobody wyboru dostawców surowców energetycznych. W ocenie A. Dudy terminal LNG umożliwiał zapewnienie dostaw gazu ziemnego już nie tylko z Rosji, ale także zbilansować mogące powstać niedobory surowca, w przypadku wystąpienia przerw w dostawach (Andrzej Duda: Lipiec?). Po trzecie - pokrycia, mogącego wystąpić w długim horyzoncie czasowym, krajowego zapotrzebowania na ten surowiec. W ocenie A. Dudy realizacja inwestycji była gwarancją (filarem) bezpieczeństwa, gdyż z uwagi na rozwój gospodarczy Polski umożliwiała zapewnienie dostaw gazu ziemnego rozwijającej się gospodarce (Olszyk 2015).

W trakcie kampanii wyborczej Andrzej Duda wielokrotnie zarzucał Ewie Kopacz, premier RP w latach 2014-2015, brak strategii rządu w zakresie polityki energetycznej Polski, którego elementem był terminal regazyfikacyjny w Świnoujściu. Jednocześnie wskazywał na brak rzetelnej informacji rządu na temat planowanego terminu oddania do użytku budowanej instalacji (Duda do rządu...). W tym kontekście kandydat PiS na urząd prezydenta podkreślał również brak zaangażowania Bronisława Komorowskiego, prezydenta RP w latach 2010-2015, w odniesieniu do realizacji inwestycji i wskazywał, że prezydent nie „działał w sprawie gazoportu, żeby np. ponaglał rząd czy apelował o ukończenie jakże ważnej dla bezpieczeństwa i suwerenności inwestycji. Jeśli prezydent ma bezpieczeństwo w swoim programie to jak on go realizuje, bo ja nie widzę kompletnie ich realizacji” (Andrzej Duda o znaczeniu...).

Formułowane przez Andrzeja Dudę postulaty w aspekcie funkcjonowania sektora gazowego oraz zapewnienia bezpieczeństwa energetycznego państwa w tym względzie dotyczyły również wydobycia gazu ziemnego z pokładów niekonwencjonalnych (gaz łupkowy) oraz umów zawieranych na dostawy tego surowca z Rosji. Kandydat PiS podkreślał w trakcie kampanii, że brak strategii energetycznej rządu doprowadził do wstrzymania poszukiwań na terytorium Polski pokładów gazu ziemnego przez zagraniczne koncerny energetyczne. Uwzględniając duży poziom uzależnienia Polski od dostaw gazu ziemnego z Rosji perspektywa wydobycia krajowego była niezwykle istotna w ramach wysiłków na rzecz zmiany struktury zużycia tego surowca. Kandydat PiS w sposób jednoznaczny określił błędną politykę rządu w tym zakresie.

W ramach kampanii wyborczej kandydat PiS na urząd prezydenta RP podkreślał również zasadność wzmocnienia bezpieczeństwa energetycznego Polski poprzez wykorzystanie krajowych zasobów surowców energetycznych. Kluczową rolę w tym względzie miał odgrywać węgiel, który był w ocenie A. Dudy „fundamentem polityki energetycznej Polski”. Kandydat PiS w trakcie kampanii podnosił, że węgiel był ważnym surowcem energetycznym z kilku powodów. Po pierwsze - stanowił podstawę bezpieczeństwa Polski. W tym kontekście przeciwstawiał się planom rządu w zakresie likwidacji kopalń i mówił, że ,nie chcę słyszeć, że polskie 
kopalnie są nierentowne, bo węgiel to jest nasz rodzimy surowiec, na którym opiera się polskie bezpieczeństwo energetyczne" (Andrzej Duda w Jastrzębiu...). Po drugie-decydował o zachowaniu suwerenności energetycznej. A. Duda podkreślał, że zmiana struktury wytwarzania energii elektrycznej w Polsce poprzez zaprzestanie wykorzystania węgla w krajowym bilansie energetycznym było sprzeczne z ,polską racją stanu" (Andrzej Duda: polskie górnictwo...; J. Dudała, Górnictwo...). Po trzecie - odgrywał ważną rolę społeczną i fiskalną. W ocenie kandydata PiS znaczenie sektora węglowego dla krajowej gospodarki było istotne $\mathrm{z}$ uwagi na liczbę osób zatrudnionych w tej branży i dlatego też wskazywał, że „to są (...) miejsca pracy, a więc dochody dla budżetu państwa" (Duda: nie ma zgody...; Andrzej Duda: węgiel...). W ramach prowadzonej kampanii A. Duda zarzucał rządowi PO-PSL brak strategii wobec tej gałęzi przemysłu a prezydentowi B. Komorowskiemu, że nie prowadził „dialogu społecznego" z przedstawicielami pracowników, związków zawodowych oraz zarządów spółek węglowych (A. Duda: Za kryzysową...).

Andrzej Duda, kandydat Prawa i Sprawiedliwości na urząd prezydent RP nie ograniczał się jedynie do krytyki rządów Platformy Obywatelskiej oraz Polskiego Stronnictwa Ludowego wobec działalności branży węglowej w Polsce, ale formułował własne wizje jego funkcjonowania. W ocenie A. Dudy sektor węglowy powinien zostać zmodernizowany, w celu dostosowania do wymogów funkcjonowania w ramach Unii Europejskiej. W efekcie podkreślał zasadność unowocześniania górnictwa oraz zwiększenia jego wydajności, gdyż jak wskazywał, „polski przemysł wydobywczy i energetyczny trzeba unowocześniać, wdrażać nowe technologie, chociażby spalania węgla czy jego przetwarzania". Kluczową rolę w tym względzie mogła odgrywać polska nauka a Polska w jego ocenia mogła „być liderem w zakresie nowych technologii węglowych” (Andrzej Duda: węgiel...; Andrzej Duda: Polski nie stać...). Jednocześnie opowiadał się za modernizacją sektora elektroenergetycznego poprzez budowę nowych bloków energetycznych o wyższej sprawności, co miało docelowo doprowadzić do ograniczenia emisji dwutlenku węgla. W ramach prowadzonej w Unii Europejskiej polityki klimatycznej kandydat PiS wskazywał na potrzebę jej weryfikacji (Andrzej Duda: węgiel...). W trakcie kampanii wyborczej A. Duda wielokrotnie podkreślał, że realizowana przez UE polityka dekarbonizacji była sprzeczna z polityką energetyczną Polski i dlatego też wskazał, że „postulowana przez Radę Europejską dekarbonizacja europejskiej gospodarki jest niszcząca dla Polski i polskiego Śląska" (Duda: dekarbonizacja...). Negatywne stanowisko wobec polityki klimatycznej UE wynikało z przekonania, że postulowane przez Komisję Europejską rozwiązania doprowadziłyby docelowo do wzrostu kosztów pozyskania energii elektrycznej oraz zmniejszenia konkurencyjności europejskiej, a tym samym polskiej gospodarki (Andrzej Duda: węgiel...; Andrzej Duda: Polski nie stać...).

Rekapitulując, należy wskazać, że w trakcie kampanii na urząd prezydenta RP w 2015 roku kandydat Prawa i Sprawiedliwości podkreślał wagę i znaczenie zagadnień energetycznych dla bezpieczeństwa państwa. W swoich wypowiedziach A. Duda wielokrotnie podnosił, że zapewnienie stabilnych dostaw surow- 
ców energetycznych oraz wykorzystanie krajowego potencjału energetycznego powinno stanowić podstawowy element polityki rządu RP. W sposób szczególny akcentował negatywne konsekwencje uzależnienia Polski od dostaw strategicznych surowców z Federacji Rosyjskiej i dlatego też podkreślał zasadność powstania infrastruktury umożliwiającej fizyczne zróżnicowanie kierunków i źródeł dostaw gazu ziemnego do Polski.

\section{UWAGI KOŃCOWE}

Charakter i specyfika wyborów prezydenckich powodowała, że kandydaci mogli w ograniczony sposób formułować deklaracje polityczne, które przyczyniłyby się do zapewnienia bezpieczeństwa energetycznego Polski. Niemniej kwestie energetyczne, $\mathrm{z}$ uwagi na ich znaczenie w dyskursie publicznym, były poruszane w enuncjacjach politycznych wszystkich kandydatów na urząd prezydenta RP w 2015 roku. W sposób szczególny tematyka ta była obecna w wypowiedziach oraz programach Bronisława Komorowskiego oraz Andrzeja Dudy, przy czym przedstawiane poglądy wynikały z odmiennego podejścia obu kandydatów do roli państwa w gospodarce w ogóle. Niewątpliwie można wskazać, że kandydat Prawa i Sprawiedliwości zasadniczo koncentrował się na dwóch aspektach (budowa terminalu regazyfikacyjnego w Świnoujściu oraz funkcjonowania spółek górniczych w Polsce), a więc tematach gdzie dokonania rządzącej od 2008 roku kolacji politycznej PO-PSL były dyskusyjne. W sposób odmienny tematyka energetyczna była poruszana przez kandydata Platformy Obywatelskiej (pełniącego wówczas funkcję prezydenta Polski), który generalnie chwalił dokonania rządów D. Tuska oraz E. Kopacz (rozbudowa infrastruktury energetycznej, idea Unii Energetycznej zaprezentowanej na forum międzynarodowym w 2014 roku).

Jednym z podstawowych tematów energetycznych poruszanych przez kandydatów na urząd prezydenta RP było funkcjonowanie sektora górnictwa węgla kamiennego w Polsce. Niewątpliwie pozytywne stanowisko wobec znaczenia tej gałęzi gospodarki (brak akceptacji zamykania kopalń) poszerzało bazę potencjalnych wyborców. W efekcie prezentowanie opinii w zakresie zamykania kopalń węglowych w znaczący sposób ograniczyłoby możliwości uzyskania pozytywnego wyniku wyborczego przez jakiegokolwiek kandydata. Dlatego też przedstawiciele Platformy Obywatelskiej oraz Prawa i Sprawiedliwości formułowali potrzebę zachowania istotnego udziału węgla w bilansie energetycznym Polski podkreślając, że był to surowiec odgrywający fundamentalne znaczenie dla bezpieczeństwa państwa. Pozostałe tematy energetyczne poruszane w kampanii wyborczej (budowa terminalu LNG, rozbudowa infrastruktury energetycznej, projekt Unii Energetycznej) nie miały znaczącego wpływu na przebieg kampanii wyborczej. Niemniej formułowane poglądy na zagadnienia energetyczne były uwarunkowane podejściem obu kandydatów do miejsca Polski na arenie międzynarodowej oraz pozycji państwa w regionie. 
Uogólniając, należy wskazać, że zarówno Bronisław Komorowski, jak i Andrzej Duda w ograniczonym zakresie poruszali zasadniczo trudne i skomplikowane tematy energetyczne. $Z$ uwagi na złożoność tematyki obaj kandydaci w sposób generalny prezentowali swoje stanowiska, przy czym niewątpliwie na ich treść wpływ miały poglądy oraz formułowane koncepcje energetyczne ich zaplecza politycznego - Platformy Obywatelskiej oraz Prawa i Sprawiedliwości.

Title: Energy security issues in Bronisław Komorowski and Andrzej Duda campaign for the office of the President of Poland in 2015

\begin{abstract}
The article analyzes the concepts formulated by the two main candidates for the office of the President of Poland in 2015. The aim of the article was therefore to analyze the ideas of Bronisław Komorowski and Andrzej Duda in the field of energy security and to identify potential points of convergence of the formulated political concepts. The views of both candidates differed significantly, which resulted from a different vision presented by the two main political groups in Poland - Civic Platform and Law and Justice, which supported these candidates.
\end{abstract}

Keywords: Bronisław Komorowski; Andrzej Duda; energy security; political thought

\title{
BIBLIOGRAFIA
}

1. Andrzej Duda o znaczeniu gazoportu w Świnoujściu, Radio Maryja, [online], https://www. radiomaryja.pl/informacje/andrzej-duda-o-znaczeniu-gazoportu-w-swinoujsciu/ [dostęp: 14.11.2021].

2. Andrzej Duda w Jastrzębiu: „Nie chcę słyszeć, że polskie kopalnie są nierentowne. Za kryzysową sytuację odpowiada rząd", wPolityce.pl, [online], https://wpolityce.pl/polityka/233697-andrzej-duda-w-jastrzebiu-nie-chce-slyszec-ze-polskie-kopalnie-sa-nierentowne-za-kryzysowa -sytuacje-odpowiada-rzad [dostęp: 10.11.2021].

3. Andrzej Duda: Jak patrzy się na budowę gazoportu widać, że wszystko jest jeszcze rozgrzebane, iswinoujscie.pl, [online], https://www.iswinoujscie.pl/drukuj/35164/ [dostęp: 15.11.2021].

4. Andrzej Duda: Lipiec? Chcemy poznać prawdziwy termin uruchomienia gazoportu!, wPolityce. pl, [online], https://wpolityce.pl/gospodarka/229315-andrzej-duda-lipiec-chcemy-poznac-prawdziwy-termin-uruchomienia-gazoportu [dostęp: 5.11.2021].

5. Andrzej Duda: Polski nie stać na odejście od węgla!, Solidarność Górnicza. Krajowa Sekcja Górnictwa Węgla Kamiennego NSZZ „Solidarność”, [online], https://www.solidarnoscgornicza. org.pl/index.php/archiwum/archiwum-wiadomosci/item/3049-andrzej-duda-polski-nie-stac-na -odejscie-od-wegla [dostęp: 8.11.2021].

6. Andrzej Duda: polskie górnictwo powinno być unowocześniane, a nie likwidowane, Onet, [online], https://wiadomosci.onet.pl/slask/andrzej-duda-polskie-gornictwo-powinno-byc-unowoczesniane-a-nie-likwidowane/vq9h686 [dostęp: 22.11.2021].

7. Andrzej Duda: węgiel jest i powinien pozostać naszym podstawowym surowcem, wnp.pl, [online], https://www.wnp.pl/gornictwo/andrzej-duda-wegiel-jest-i-powinien-pozostac-naszym -podstawowym-surowcem,244861.html [dostęp: 19.11.2021].

8. Andrzej Duda: Za kryzysową sytuację w górnictwie odpowiada rząd, interia.pl, [online], https:// wydarzenia.interia.pl/kraj/news-a-duda-za-kryzysowa-sytuacje-w-gornictwie-odpowiada-rzad,nId,1672106 [dostęp: 12.11.2021]. 
9. Bronisław Komorowski złożył życzenia górnikom, Prezydent.pl, [online], https://www.prezydent.pl/kancelaria/archiwum/archiwum-bronislawa-komorowskiego/aktualnosci/wizyty-krajowe/bronislaw-komorowski-zlozyl-zyczenia-gornikom,15785 [dostęp: 4.11.2021].

10. Duda do rządu: Chcemy poznać prawdziwy termin końca budowy gazoportu w Świnoujściu, TV Republika, [online], https://tvrepublika.pl/duda-do-rzadu-chcemy-poznac-prawdziwy-termin-konca-budowy-gazoportu-w-swinoujsciu,15854.html [dostęp: 2.11.2021].

11. Duda: dekarbonizacja niszcząca dla Polski i Śląska, TVP3 Katowice, [online], https://katowice. tvp.pl/19329139/duda-dekarbonizacja-niszczaca-dla-polski-i-slaska [dostęp: 25.11.2021].

12. Duda: nie ma zgody na zamykanie polskich kopalń, wnp.pl, [online], https://www.wnp.pl/gornictwo/duda-nie-ma-zgody-na-zamykanie-polskich-kopaln,250723.html [dostęp: 19.11.2021].

13. Dudała J., Górnictwo: przeciwstawmy się polityce dekarbonizacji!, wnp.pl, [online], https:// www.wnp.pl/energetyka/przeciwstawmy-sie-polityce-dekarbonizacji,251932.html [dostęp: 25.10.2021].

14. Paszkowski M. (2015), Specyfika badań politologicznych nad myślą polityczną w zakresie bezpieczeństwa energetycznego państwa, „Humanities and Social Sciences”, nr 2 (22).

15. Paszkowski M. (2017), Polskie projekty na rzecz wzmocnienia bezpieczeństwa energetycznego w Europie w myśli politycznej Prawa i Sprawiedliwości oraz Platformy Obywatelskiej, „Polityka i Społeczeństwo", nr 2 (15).

16. Plan Działań dla Polski. Co osiągnęliśmy i co dalej?, Prezydent.pl, [online], https://www.prezydent.pl/kancelaria/archiwum/archiwum-bronislawa-komorowskiego/prezydent/plan-dzialan -dla-polski .[dostęp: 22.11.2021].

17. S. Olszyk (2015), Polityka bezpieczeństwa i obrony Polski w retoryce wyborczej kandydatów na Urząd Prezydenta RP w 2015 roku - Andrzej Duda vs. Bronisław Komorowski, „Rocznik Instytutu Europy Środkowo-Wschodniej”, z. 1 (13).

18. Ustawa służy wypełnieniu porozumienia z górnikami, Prezydent.pl, [online], https://www.prezydent.pl/kancelaria/archiwum/archiwum-bronislawa-komorowskiego/aktualnosci/wydarzenia/ ustawa-sluzy-wypelnieniu-porozumienia-z-gornikami,15587 [dostęp: 25.11.2021]. 